Jurnal Keperawatan Silampari

Volume 4, Nomor 2, Juni 2021

e-ISSN: 2581-1975

p-ISSN: $2597-7482$

DOI: https://doi.org/10.31539/jks.v4i2.1864

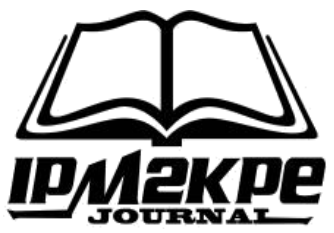

\title{
PENGGUNAAN CITRUS ORANGE SEBAGAI ALTERNATIF MENURUNKAN KECEMASAN PASIEN HEMODIALISIS
}

\author{
Yeni Kartika Sari ${ }^{1}$, Okky Cintya Permata Dewi ${ }^{2}$, Wahyu Wibisono ${ }^{3}$, \\ Ning Arti Wulandari ${ }^{4}$ \\ Sekolah Tinggi Ilmu Kesehatan Patria Husada Blitar ${ }^{1,2,3,4}$ \\ kartikasariyeni84@gmail.com ${ }^{1}$
}

\begin{abstract}
ABSTRAK
Penelitian ini bertujuan untuk mengetahui pengaruh pemberian aromaterapi citrus (orange) terhadap kecemasan pada pasien hemodialisis. Desain penelitian ini adalah praeksperimental dengan one group pre-post test design. Hasil penelitian menggunakan uji paired $\mathrm{t}$ test didapatkan $\mathrm{p}$ value 0,000. Rata-rata skor kecemasan sebelum pemberian aromaterapi citrus (orange) adalah 51,20 dan setelah pemberian aromaterapi citrus (orange) adalah 34,45. Simpulan, pemberian aromaterapi citrus (orange) berpengaruh terhadap kecemasan pada pasien hemodialisis.
\end{abstract}

Kata Kunci: Citrus Orrange, Hemodialisis, Kecemasan

\section{ABSTRACT}

This study aims to determine the effect of giving citrus aromatherapy (orange) on anxiety in hemodialysis patients. This research design is pre-experimental with one group pre-post test design. The results of the study using the paired t-test obtained a p-value of 0.000 . Before administering citrus aromatherapy (orange), the average anxiety score was 51.20 and after administration of citrus aromatherapy (orange) was 34.45. In conclusion, giving citrus aromatherapy (orange) affects anxiety in hemodialysis patients.

Keywords: Citrus Orange, Hemodialysis, Anxiety

\section{PENDAHULUAN}

Penyakit Ginjal Kronis (PGK) merupakan masalah kesehatan masyarakat global dengan insiden gagal ginjal yang meningkat, prognosis yang buruk dan biaya yang tinggi. Di Indonesia, perawatan penyakit ginjal merupakan ranking kedua pembiayaan terbesar kesehatan setelah penyakit jantung. Gagal Ginjal Kronis (GGK) di Indonesia menempati urutan kedua terbesar dalam penggunaan asuransi kesehatan setelah penyakit jantung. Terdapat 30.554 pasien yang aktif menjalani hemodialisis sepanjang tahun 2015, dimana sebagian besar adalah akibat GGK (Kementrian Kesehatan RI, 2020).

Hemodialisis adalah tindakan yang dilakukan untuk menggantikan fungsi ginjal (Wijaya \& Padila, 2019). Tindakan ini dilakukan secara rutin pada pasien GGK stadium lima. Berdasarkan data dari Indonesian Renal Registry (2013), jumlah pasien di unit 
hemodialisis tahun 2012 sekitar 19.621 orang pasien baru dan pasien aktif sebanyak 9.161 orang. Lebih dari 70\% negara-negara melaporkan sedikitnya 80\% dari pasien menggunakan terapi Hemodialisis (HD) (Kementrian Kesehatan RI, 2020).

Depresi dan kecemasan merupakan gejala yang sering ditemukan pada pasien yang sedang menjalani hemodialis. Kualitas hidup pasien, komorbiditas dan hilangnya akses vaskuler merupakan faktor yang berkaitan dengan gejala tersebut (De-Brito et al., 2019). Hasil penelitian lain yang dilakukan oleh Kamil et al., (2018) menunjukkan bahwa kecemasan merupakan masalah yang umum terjadi pada pasien yang sedang menjalani hemodialisis.

Kecemasan pada pasien hemodialisis jika dibiarkan akan mengakibatkan berbagai masalah seperti penolakan tindakan yang berakibat meningkatkan kadar ureum dan kreatinin kemudian menyebabkan penurunan fungsi ginjal dan berakibat pada kematian. Selain itu kecemasan yang berkepanjangan dapat mempengaruhi sistem kekebalan tubuh. Kecemasan memicu produksi hormon kortisol yang akan mengganggu fungsi sel $\mathrm{T}$ dalam melawan infeksi, sehingga meningkatkan resiko berbagai penyakit yang mudah menyerang seperti flu dan masalah fisik berat lainnya seperti stroke hingga penyakit jantung.

Dampak terjadinya kecemasan secara fisik adalah terjadinya peningkatan frekuensi nadi dan respirasi, peningkatan tekanan darah, penurunan kerja otot polos pada kandung kemih dan usus. Salah satu alternatif terapi yang bisa dilakukan oleh perawat untuk mengatasi kecemasan pasien adalah dengan teknik relaksasi karena biayanya murah dan dapat dilakukan diberbagai tempat dan keadaan. Aromaterapi merupakan salah satu metode relaksasi yang dapat dilakukan pada pasien hemodialisis dengan menggunakan minyak essensial dari tumbuhan yang dapat mempengaruhi suasana hati atau kesehatan seseorang (Karadag \& Baglama, 2019).

Banyak aromaterapi yang dapat dipilih untuk relaksasi. Salah satunya adalah citrus (orange) yang merupakan minyak essensial dengan bahan dasar kulit jeruk. Bahan dasar dasar ini dipilih karena mengandung minyak atsiri yang memiliki kandungan limonen sebanyak (94\%), linalool sebanyak (2\%), linalil asetat dan tripenol sebanyak (1\%). Linalool, linalil asetat dan terpineol bersifat sebagai penenang (sedatif), limonen juga berfungsi untuk menenangkan (sedatif), serta melancarkan peredaran darah dan juga menghambat sel kanker. Dengan banyaknya kandungan yang bersifat menenangkan (sedatif) maka aromaterapi ini menjadi salah satu pilihan yang baik untuk menurunkan kecemasan (Alfianur, 2017). Penelitian ini menggunakan arometarapi citrus (orange) merek Azarine produk PT Wahana Kosmetika Indonesia yang sudah terdaftar di BPOM.

Penelitian yang dilakukan pada tahun 2013 menunjukkan bahwa citrus (orange) aromatherapy dapat menurunkan pulse rate dan tingkat hormon stress pada anak yang sedang menjalani prosedur pada giginya. Pada tahun 2015 penelitian lain juga menunjukkan bahwa wanita yang sedang melahirkan melaporkan kecemasannya lebih berkurang setelah mengirup aromaterapi orange daripada kelompok kontrol yang hanya menghirup distilled water. Sedangkan penelitian pada tahun 2019 yang dilakukan pada tikus, menunjukkan bahwa tikus yang menghirup aromaterapi orange tidak menunjukkan perilaku depresi (Schulman, 2019). Cara yang paling mudah untuk menggunakan citrus (orange) aromatherapy adalah dengan menghirupnya baik melalui diffuser yang akan menyebarkannya melalui udara maupun meneteskannya pada pada obyek seperti bantal pada saat tidur (Macmillan, 2019). 
Penelitian yang dilakukan oleh Alfikrie et al., (2020) pada 30 responden menunjukkan bahwa latihan nafas dalam dapat mengurangi kecemasan pada pasien yang sedang menjalani hemodialisis. Sedangkan penelitian yang dilakukan oleh Pramono et al., (2019) menunjukkan bahwa latihan otot progresif merupakan teknik relaksasi yang memiliki dampak signifikan pada tingkat kecemasan pada pasien yang sedang menjalani hemodialisis. Meskipun kedua teknik relaksasi tersebut terbukti dapat menurunkan kecemasan pada pasien yang sedang menjalani hemodialisis, akan tetapi kedua tindakan tersebut memerlukan usaha atau energi dari pasien. Sedangkan pada penelitian ini menggunakan aromaterapi citrus (orange) sebagai alternatif untuk mengatasi kecemasan pasien yang menjalani hemodialisis tanpa memerlukan usaha atau energi dari pasien.

\section{METODE PENELITIAN}

Penelitian ini merupakan pra-eksperimental dengan desain one group pre-post test, dimana observasi kecemasan dilakukan pada sekelompok pasien hemodialisis sebelum dan sesudah diberikan relaksasi menggunakan citrus (orange).

Populasi pada penelitian ini berjumlah 88 orang, sedangkan jumlah sampelnya berdasarkan rumus Issac adalah 20 orang. Adapun kriteria pasien yang dapat menjadi responden adalah pasien dengan kesadaran kompos mentis, tidak mempunyai gangguan penciuman dan tidak mempunyai alergi terhadap aromaterapi yang akan diberikan.

Penelitian dilakukan dengan melakukan observasi tingkat kecemasan sebelum dan sesudah pemberian aromaterapi citrus (orange), menggunakan kuisioner Zung Self-Rating Anxiety Scale (SAS/SRAS). Cara pemberiannya dengan meneteskan essensial oil 1-5 tetes pada tissu kering \& di letakkan di dada pasien untuk dihirup selama 10 menit sambil menarik napas dalam 2-3 kali, istirahat 60 menit, diberikan lagi 10 menit. Perlakuan sebanyak 2 kali kedatangan pasien hemodialisis secara berturut-turut. Data yang diperoleh berupa data interval yang akan dinalisis menggunakan paired t-test.

\section{HASIL PENELITIAN Karakteristik Responden}

Tabel. 1

Distribusi Frekuensi Karakteristik Responden

\begin{tabular}{lcc}
\hline \multicolumn{1}{c}{ Karakteristik } & Frekuensi (f) & Presentase (\%) \\
\hline Usia (th) & 4 & 20 \\
Dewasa Awal (20-40) & 14 & 70 \\
Dewasa Tengah (41-60) & 2 & 10 \\
Lansia Akhir/ Lansia (> 60) & & \\
\hline Jenis Kelamin & 11 & 55 \\
Laki-Laki & 9 & 45 \\
Perempuan & & 15 \\
Tingkat Pendidikan & 3 & 10 \\
Tamat SD & 2 & 35 \\
Tamat SMP & 7 & 40 \\
Tamat SMA & 8 & \\
Tamat Perguruan Tinggi & & \\
& & \\
\hline
\end{tabular}




\begin{tabular}{lcc}
\hline Pekerjaan & 11 & \\
Bekerja & 9 & 55 \\
Tidak Bekerja & & 45 \\
\hline Status Pernikahan & 19 & 95 \\
Menikah & 1 & 5 \\
Tidak Menikah & & \\
\hline Penyakit Penyerta & 8 & 40 \\
Diabetes Melitus & 12 & 60 \\
Hipertensi &
\end{tabular}

Berdasarkan tabel 1 menunjukkan bahwa $70 \%$ berusia dewasa tengah, $55 \%$ berjenis kelamin laki-laki, 40\% menyelesaikan pendidikan tinggi, 55\% masih bekerja, 95\% berstatus menikah, dan $60 \%$ memiliki penyakit penyerta hipertensi.

\section{Analisis Pengaruh Pemberian Aromaterapi Citrus (Orange) pada Pasien Hemodialisis}

Tabel. 2

Analisis Pengaruh Pemberian Aromaterapi Citrus (Orange) pada Pasien Hemodialisis

\begin{tabular}{lcccc}
\hline Skor Kecemasan Sebelum & Mean & Median & Modus & Min-Max \\
& 51,20 & 51,5 & 54 & $45-58$ \\
\hline Skor Kecemasan Sesudah & Mean & Median & Modus & Min-Max \\
& 34,45 & 35 & 28 & $26-42$ \\
\hline & & & P value $=$ \\
& & & 0,000 & \\
\hline
\end{tabular}

Berdasarkan tabel 2 menunjukkan bahwa hasil perhitungan statistik menggunakan paired t-test menunjukkan ada pengaruh pemberian citrus (orange) terhadap kecemasan pasien hemodialisis dengan $p$ value $=0,000$. Rata rata skor kecemasan juga menunjukkan ada perbedaan antara sebelum dan sesudah pemberian citrus (orange).

\section{PEMBAHASAN}

\section{Kecemasan Pasien Hemodialisis Sebelum Diberikan Aromaterapi Citrus (Orange)}

Kecemasan pasien sebelum diberikan aromaterapi citrus (orange) didapatkan mean 51,20. Munculnya kecemasan tersebut dikarenakan terkejut akibat mengetahui kondisi penyakit gagal ginjalnya dan karena nyeri akibat prosedur hemodialisis yang dijalaninya (Goyal et al., 2018). Hal ini sesuai dengan penelitian yang dilakukan oleh De-Brito et al., (2019) bahwa depresi dan kecemasan merupakan gejala yang sering ditemukan pada pasien yang sedang menjalani hemodialis. Kualitas hidup pasien, komorbiditas dan hilangnya akses vaskuler merupakan faktor yang berkaitan dengan gejala tersebut.

Dalam penelitian ini diperoleh hasil dari 20 orang responden $70 \%$ nya berada pada usia dewasa tengah (41-60 tahun). Dari jumlah tersebut tidak ada perbedaan kecemasan antara usia muda dengan usia tua, sehingga sejalan dengan pernyataan Alfikrie et al., (2020) bahwa umur, jenis kelamin, status pernikahan dan pekerjaan tidak berhubungan dengan kecemasan pasien yang sedang menjalani hemodialisis. Penelitian yang sama juga 
menunjukkan bahwa pasien yang bekerja tidak berdampak pada kecemasan pasien yang menjalani hemodialisis (Turkistani et al., 2018).

Penelitian ini juga penunjukkan bahwa tidak ada perbedaan kecemasan antara pasien dengan latar belakang pendidikan tinggi dan latar belakang pendidikan rendah karena kecemasan juga dapat disebabkan oleh kurangnya informasi yang diperoleh. Hal ini dapat dijelaskan oleh penelitian yang dilakukan oleh Nisar et al., (2017) bahwa pendidikan tidak berpengaruh signifikan terhadap kejadian depresi pada pasien. Penelitian ini sejalan dengan penelitian Goyal et al., (2018) bahwa pendidikan tidak memiliki hubungan yang signifikan dengan tingkat kecemasan pada pasien yang sedang menjalani hemodialisis.

\section{Kecemasan Pasien Hemodialisis Setelah Diberikan Aromaterapi Citrus (Orange)}

Berdasarkan hasil penelitian tingkat kecemasan pasien setelah diberikan aromaterapi citrus (orange) didapatkan mean 34,45. Hal ini dapat disimpulkan bahwa setelah pemberian aromaterapi cytus (orange) terdapat penurunan tingkat kecemasan pada pasien yang melakukan hemodialisis. Sebelum pemberian aromaterapi citrus (orange) pasien menunjukkan adanya penyempitan lapang persepsi, penurunan perhatian dan konsentrasi terhadap proses yang terjadi disekitarnya, namun setelah pemberian aromaterapi citrus (orange) terjadi hal yang sebaliknya. Dari penelitian ini di dapat rata-rata penurunan skor kecemasan dengan rata-rata $16,75$.

Setelah dilakukan uji statistik dengan menggunakan uji paired t test didapatkan ada pengaruh pemberian aromaterapi citrus (orange) terhadap kecemasan pada pasien hemodialisis $(p<0,05)$. Johns Hopkins Medicines mengatakan bahwa ketika aromaterapi citrus (orange) dihirup, molekul aroma dalam minyak esensial bergerak dari saraf penciuman langsung menuju otak dan akan berdampak pada amigdala sebagai pusat emosi pada otak. Hipotalamus bertindak sebagai pemancar dan pengatur menyampaikan pesan ke bagian lain dari otak dan bagian tubuh. Pesan yang diterima kemudian diubah menjadi tindakan berupa pelepasan hormon melatonin dan serotonin yang menyebabkan euphoria, rileks atau sedatif.

Senyawa dalam minyak atsiri ini adalah limonen sebanyak (94\%), linalool sebanyak (2\%), linalil asetat dan tripenol sebanyak (1\%). Linalool, linalil asetat dan terpineol bersifat sebagai penenang (sedatif), limonen juga berfungsi untuk menenangkan (sedatif), serta melancarkan peredaran darah dan juga menghambat sel kanker. Dengan banyaknya kandungan yang bersifat menenangkan (sedatif) maka aromaterapi ini menjadi salah satu pilihan yang baik untuk menurunkan kecemasan (Alfianur, 2017). Dari hasil penelitian ini dapat disimpulkan bahwa terjadinya penurunan kecemasan pada pasien hemodialisis dikarenakan pemberiaan aromaterapi citrus (orange) yang memberikan efek relaksasi untuk pasien. Sehingga pemberian aromaterapi citrus (orange) dapat diberikan sebagai salah satu terapi untuk mengurangi kecemaan pasien yang menjalani hemodialisis.

\section{SIMPULAN}

Pemberian aromaterapi citrus (orange) berpengaruh terhadap kecemasan pada pasien hemodialisis. 


\section{SARAN}

Berdasarkan penelitian dan pembahasan mengenai pemberian aromaterapi citrus (orange) pada pasien yang sedang menjalani hemodialisis, diharapkan perawat dapat menggunakan teknik relaksasi menggunakan aromaterapi citrus (orange) untuk menurunkan kecemasan pasien hemodialisis.

\section{DAFTAR PUSTAKA}

Alfianur, A. (2017). Identifikasi Komponen Penyusun Minyak Atsiri Kulit Jeruk Manis (Citrus sinensis L.) Asal Selorejo dan Uji Aktivitas Antibakteri Menggunakan Metode Kertas Cakram [Universitas Islam Negeri Maulana Malik Ibrahim Malang]. In Universitas Islam Negeri Maulana Malik Ibrahim. http://etheses.uinmalang.ac.id/11031/1/13630118.pdf

Alfikrie, F., Purnomo, A., \& Selly, R. (2020). Pengaruh Relaksasi Dzikir terhadap Tingkat Kecemasan Pasien Gagal Ginjal Kronis yang Menjalani Hemodialisa. Jurnal Keperawatan Padjadjaran, 2(2), 18-24. https://doi.org/10.24198/jkp.v3n1.3

De-Brito, D. C. S., Machado, E. L., Reis, I. A., De Freitas do Carmo, L. P., \& Cherchiglia, M. L. (2019). Depression and Anxiety among Patients Undergoing Dialysis and Kidney Transplantation: A Cross-Sectional Study. Sao Paulo Medical Journal, 137(2), 137-147. https://doi.org/10.1590/1516-3180.2018.0272280119

Goyal, E., Chaudhury, S., \& Saldanha, D. (2018). Psychiatric Comorbidity in Patients Undergoing Hemodialysis. Industrial Psychiatry Journal, 27(2), 206. https://doi.org/10.4103/ipj.ipj_5_18

Kamil, I., Agustina, R., \& Wahid, A. (2018). Gambaran Tingkat Kecemasan Pasien Gagal Ginjal Kronik yang Menjalani Hemodialisis di RSUD Ulin Banjarmasin. Dinamika Kesehatan, $9(2)$, 366-377. https://ojs.dinamikakesehatan.unism.ac.id/index.php/dksm/article/view/350

Karadag, E., \& Baglama, S. S. (2019). The Effect of Aromatherapy on Fatigue and Anxiety in Patients Undergoing Hemodialysis Treatment: A Randomized Controlled Study. $\begin{array}{llll}\text { Holistic Nursing } & \text { Practice, } & 33(4),\end{array}$ https://doi.org/10.1097/HNP.0000000000000334

Kementrian Kesehatan RI. (2020). Data dan Informasi Profil Kesehatan Indonesia 2019. Kementrian Kesehatan RI, 8(9), 1-58

Macmillan, A. (2019). So Essensial Oils Work for Anxiety-and What are the Best Ones? (p. 27). https://www.health.com/anxiety/essential-oils-for-anxiety

Nisar, S., Uzair, A., Khan, A. M., \& Akhtar, S. (2017). Association of Depression with Socio-Demographic Factors in Patients Undergoing Hemodialysis. Pakistan Armed Forces Medicine Journal, 67(2), 232-237. http://www.pafmj.org/art_pdf/1181.pdf

Pramono, C., Hamranani, S. S. T., \& Sanjaya, M. Y. (2019). Pengaruh Teknik Relaksasi Otot Progresif terhadap Tingkat Kecemasan Pasien Hemodialisa di RSUD Wonosari. Jurnal Ilmu Keperawatan Medikal Bedah, 2(2), 22. https://doi.org/10.32584/jikmb.v2i2.248

Schulman, J. S. (2019). The Benefits of Orange Essential Oil and How to Use. In Healthline. https://www.healthline.com/health/orange-essential-oil-uses 
Turkistani, I., Nuqali, A., Badawi, M., Taibah, O., Alserihy, O., Morad, M., \& Kalantan, E. (2018). The Prevalence of Anxiety and Depression among End-Stage Renal Disease Patients on Hemodialysis in Saudi Arabia. Renal Failure, 8(1), 55-62. https://doi.org/10.3109/0886022X.2014.949761

Wijaya, A. K., \& Padila, P. (2019). Hubungan Dukungan Keluarga, Tingkat Pendidikan dan Usia dengan Kepatuhan dalam Pembatasan Asupan Cairan pada Klien Esrd yang Menjalani Terapi Hemodialisa. Jurnal Keperawatan Silampari, 3(1), 393-404. https://doi.org/https://doi.org/10.31539/jks.v3i1.883 